\title{
A GEOCHEMICAL STUDY OF PERIDOTITC DIAMONDS FROM PREMIER MINE
}

\author{
Kerryn Whitehead ${ }^{1}$ and Stephen H. Richardson ${ }^{1}$ \\ ${ }^{1}$ University of Cape Town, South Africa
}

\section{INTRODUCTION}

The Premier mine is a group I kimberlite situated in the centre of the Kaapvaal craton, $30 \mathrm{~km}$ ENE of Pretoria. It has been dated at $1180 \pm 30 \mathrm{Ma}$ (Allsopp \& Kramers, 1977), which is much younger than the Bushveld Igneous Complex into which it intrudes $(2060 \mathrm{Ma}$, Walraven et al., 1987). The suite chosen for study consists of 95 peridotitic diamonds; which contain garnet and/or clinopyroxene mineral inclusions, as well as minor olivine and orthopyroxene. Also included in the sample set are the fragments of 19 diamonds from Premier mine, these diamonds were used in a previous study by Richardson et al. (1993). The fragments were used in this study for FTIR and stable isotope analysis. The mineral chemistry of the garnet inclusions from the fragments has been included with the analyses of this study. The age of formation of the harzburgitic paragenesis has been inferred to be $3.2 \mathrm{Ga}$, by comparison with harzburgitic diamonds from Kimberley and Finsch and the age of the lherzolitic paragenesis has been dated at $1.93 \mathrm{Ga}$ (Richardson et al., 1993).

\section{PHYSICAL CHARACTERISTICS}

Table 1 shows that the diamonds selected for this study contain peridotitic inclusions with $\mathrm{Cr}$-pyrope occurring in $61 \%$ of the diamonds, followed by $\mathrm{Cr}$-diopside $(59 \%)$, olivine $(10 \%)$, and enstatite (3\%). The inclusions were commonly cubo-octahedral and often flattened, indicating that the inclusions are syngenetic, as the inclusion's morphology has been imposed by the diamond (Harris \& Gurney, 1979). The diamonds are mostly octahedral (45\%), 29\% are macles, $15 \%$ are tetrahexahedroids, $10 \%$ are octahedral aggregates and 1 is irregular. The majority of diamonds are brown (93\%) and the remainder are colourless (7\%). The diamonds were selected for their peridotitic inclusion contents and are thus not representative of the overall population at Premier.

\section{Table 1: Inclusion abundance for Premier diamonds}

\begin{tabular}{lc}
\hline Mono-mineralic & $\%$ \\
assemblages & \\
\hline Pyrope (gt) & 32.7 \\
Cr-diopside (cpx) & 34.5 \\
Enstatite (opx) & 0 \\
Olivine (ol) & 0 \\
\hline \multicolumn{2}{l}{} \\
\hline Bi-mineralic & $\%$ \\
assemblages & \\
\hline gt-cpx & 17.3 \\
gt-ol & 5.4 \\
gt-opx & 1.8 \\
cpx-ol & 3.6 \\
\hline \multicolumn{2}{|l}{} \\
\hline asi-mineralic & $\%$ \\
\hline gt-cpx-ol & 0.9 \\
gt-cpx-opx & 0.9 \\
(gt-cpx touching) & \\
\hline
\end{tabular}

\section{NITROGEN AGGREGATION CHARACTERISTICS}

There is a broad range in nitrogen concentration for this suite of diamonds, from near 0 to $858 \mathrm{ppm}$. Many contain minimal nitrogen and are classed as Type II diamonds $(55 \%)$. The rest of the diamonds contain significant nitrogen and are Type IaAB. The range of nitrogen as B aggregates is also broad from 35 to $99 \%$. The average mantle residence temperatures can be calculated from the nitrogen aggregation state, using an average mantle residence time of $0.75 \mathrm{Ga}$ for both the harzburgitic and lherzolitic diamonds. It is assumed that the harzburgitic diamonds have recrystallized at $1.93 \mathrm{Ga}$ during the formation of the lherzolitic paragenesis, as the average mantle residence temperatures for both groups are within $5{ }^{\circ} \mathrm{C}$ of each other. The average temperatures for the harzburgitic 
and lherzolitic parageneses are 1224 and $1219{ }^{\circ} \mathrm{C}$ respectively. This is possibly due to the intrusion of the Bushveld Igneous Complex at $2.06 \mathrm{Ga}$ (Walraven et al., 1987). The range of average mantle residence temperatures for the individual diamonds is 1171 $1304^{\circ} \mathrm{C}$.

Plates were cut from thirteen diamonds for cathodoluminescence imaging and further detailed FTIR analysis. The majority of the plates show octahedral growth zones, with mixed Type I and Type II growth. Some plates show areas of partial resorption before a new layer of growth begins (Figure 1). The temperatures obtained from the plates $\left(1168-1333^{\circ} \mathrm{C}\right)$ are similar to the range obtained for the rough diamonds. Detailed FTIR analysis has shown an overall decrease in temperature from the core to the rim for the majority of the plates.

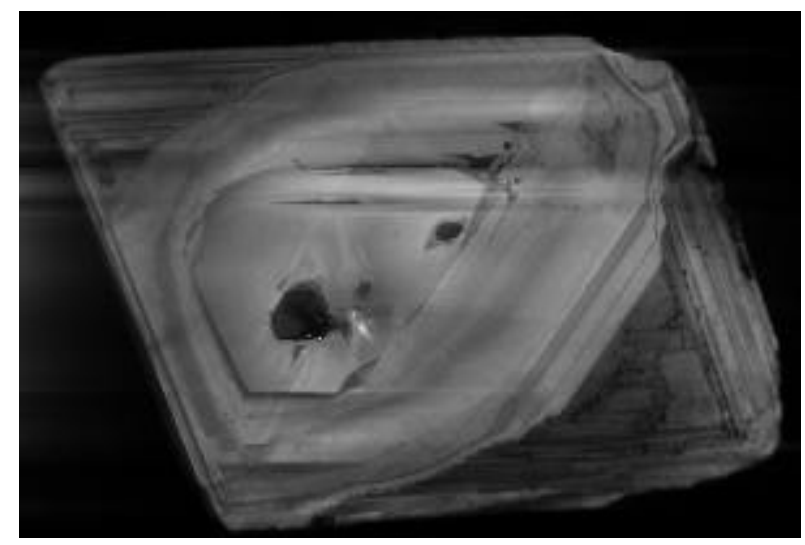

Figure 1: A cathodoluminescence image of an octahedral diamond. The light areas are Type I (contain nitrogen) and the dark areas are Type II (contain no nitrogen). Partial resorption followed by Type II growth is especially evident around the inner octahedral growth zones. The two dark spots are inclusion pits.

\section{CARBON AND NITROGEN ISOTOPES}

The range of carbon isotopes obtained for this suite is -10.3 to $-1.0 \%$, with a mean of $-4.06 \%$ o $( \pm 1.491$ sigma). The mean is heavier, but within error, of the mean obtained for peridotitic diamonds at Premier by Deines et al. (1984) of $-5.13 \%$ ( \pm 2.171 sigma $)$. This difference in mean isotope values may be related to the number of diamonds analysed; 95 diamonds were analysed in this study in comparison with 19 P-Type diamonds of Deines et al. (1984). The shift in the mode to heavier $\ddot{a}^{13} \mathrm{C}$ values in this study, compared with the worldwide mode, is most likely reflecting the variability of individual source regions. The diamonds containing lherzolitic inclusions have heavier mean $\mathrm{C}$ isotope compositions $(-3.8 \%$ ) than those containing harzburgitic inclusions $(-4.3 \%$ ), which suggests there may be an evolution of the carbon source region over time to heavier isotopic compositions.

The range of nitrogen isotopes obtained is -24.5 to +10.2 $\%$. These values extend the range of nitrogen isotopes in the "high $\ddot{a}^{13} \mathrm{C}$ " group (Figure 2) as defined by Boyd \& Pillinger (1994) and are similar to the nitrogen isotope values obtained for peridotitic diamonds from Fuxian, China, by Cartigny et al. (1997).

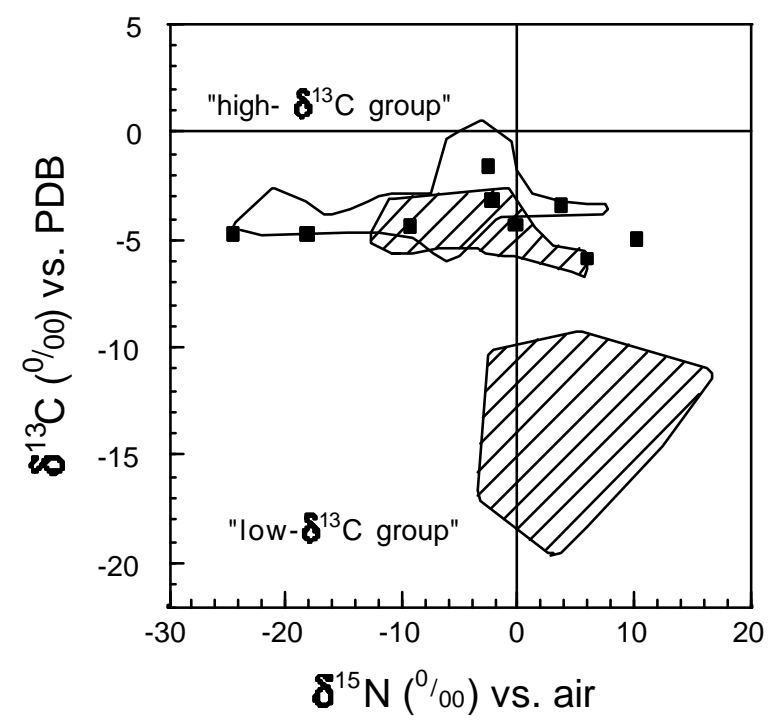

Figure 2: A plot of $\ddot{a}^{13} \mathrm{C}(\% \circ)$ vs. $\ddot{a}^{15} \mathrm{~N}(\% \circ)$ for diamonds showing the "high-ä ${ }^{13} \mathrm{C}$ " group and "low-ä ${ }^{13} \mathrm{C}$ " group of Boyd and Pillinger (1994, hatched field) and the field obtained by Cartigny et al. (1998) for diamonds from Fuxian (blank field). Squares=samples from this study.

\section{MINERAL CHEMISTRY}

\section{GARNET}

The garnet inclusions fall into the range defined for $\mathrm{Cr}$ pyrope garnets worldwide. The garnets have $\mathrm{Mg}$ numbers of 79.2-90.7 [\%] and they are characterised by high $\mathrm{MgO}$ (17 - 25\%), high $\mathrm{Cr}_{2} \mathrm{O}_{3}$ (up to 20\%), low 
$\mathrm{CaO}(0.6-7 \%)$ and low $\mathrm{FeO}(4-12 \%)$. A plot of $\mathrm{CaO}$ vs. $\mathrm{Cr}_{2} \mathrm{O}_{3}$ shows the separation of harzburgitic and lherzolitic garnets (Figure 3).

\section{CLINOPYROXENE}

The Mg-numbers range from 89.2 - 94.0 [mol\%]. The range of major element chemistry is similar to that previously obtained for Premier (Kimberlite Research Group Database): $\mathrm{TiO}_{2}$ is $0-1.10 \mathrm{wt} \%, \mathrm{Al}_{2} \mathrm{O}_{3}$ is $0.63-$ $6.94 \mathrm{wt} \%, \mathrm{Cr}_{2} \mathrm{O}_{3}$ is $0.09-2.97 \mathrm{wt} \%, \mathrm{MnO}$ is $0.05-0.15$ $\mathrm{wt} \% \mathrm{CaO}$ is $12.30-20.95 \mathrm{wt} \%, \mathrm{NaO}$ is $0.40-5.15 \mathrm{wt} \%$ and $\mathrm{K}_{2} \mathrm{O}$ is $0-0.08 \mathrm{wt} \%$.

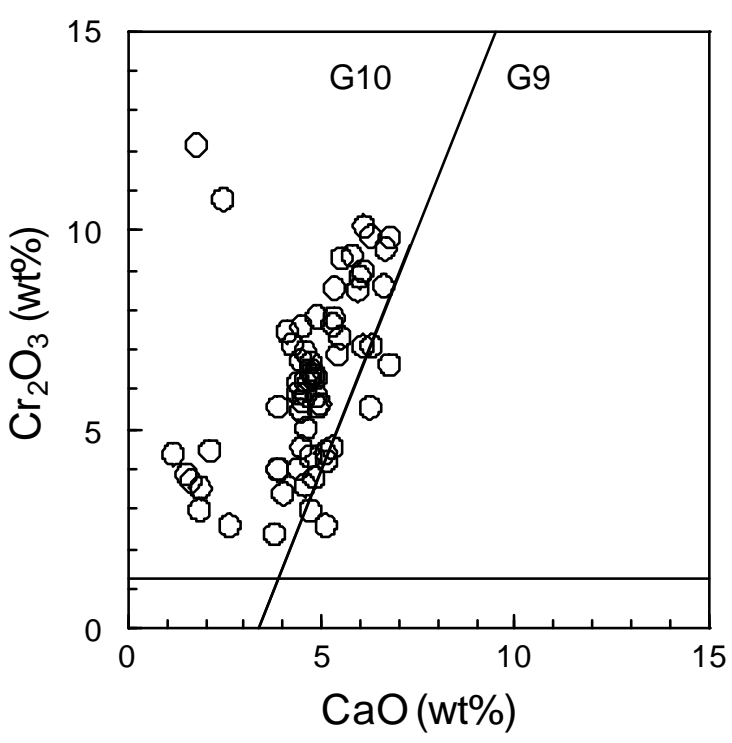

Figure 3: A plot of $\mathrm{Cr}_{2} \mathrm{O}_{3}$ vs. $\mathrm{CaO}$ for garnet inclusions showing the line separating the lherzolite paragenesis (G10) and the harzburgitic paragenesis (G9; after Gurney, 1984).

\section{ORTHOPYROXENE}

The four colourless enstatite inclusions have a narrow range of Mg-numbers (92.6 - 93.4 [mol\%]), and lie towards the lower end of the worldwide range (92.5 96 mol\%; Stachel \& Harris, 1997). The range of $\mathrm{MnO}$ values is $0.09-0.12 \mathrm{wt} \%$ and $\mathrm{CaO}$ values range from 1.05-1.20 wt\%, these high $\mathrm{CaO}$ values are indicative of enstatite crystallising in equilibrium with $\mathrm{Cr}$-diopside. $\mathrm{Na}_{2} \mathrm{O}$ ranges from $0-0.15 \mathrm{wt} \%$ and $\mathrm{K}_{2} \mathrm{O}$ is not detected (0-0.01 wt\%). $\quad \mathrm{Al}_{2} \mathrm{O}_{3}$ has a wide range of values from 0.32-1.02 wt $\%$ and $\mathrm{Cr}_{2} \mathrm{O}_{3}$ ranges from 0.13-0.43 wt\%.

\section{OLIVINE}

The olivine inclusions have a narrow range of forsterite values (90.9 to $93.3 \mathrm{~mol} \%$ ). The most refractory olivine inclusions coexisted with harzburgitic garnets and the least refractory olivine inclusions coexisted with clinopyroxene inclusions. $\mathrm{NiO}$ ranges from $0.41-$ $0.61 \mathrm{wt} \%$ with the higher values corresponding to the lherzolitic assemblage and the lower values to the harzburgitic assemblage. The values obtained for the other major elements are: $\mathrm{Al}_{2} \mathrm{O}_{3}(0-0.05 \mathrm{wt} \%), \mathrm{Cr}_{2} \mathrm{O}_{3}$ (0.01-0.12 wt \%), $\mathrm{FeO}(6.5-8.8$ wt\%), $\mathrm{MnO}(0.08-0.14$ wt $\%), \mathrm{MgO}(45.4-50.8 \mathrm{wt} \%)$ and $\mathrm{CaO}(0.01-0.12 \mathrm{wt} \%)$.

\section{GEOTHERMOBAROMETRY}

The thermometer of Nimis \& Taylor (2000) using the chemistry of the clinopyroxene inclusions yields a range of temperatures from 877 to $1295{ }^{\circ} \mathrm{C}$ (average $\left.1089{ }^{\circ} \mathrm{C}\right)$. The thermometer of Krogh (1988) on coexisting garnet and clinopyroxene inclusions yields a range of temperatures from 1028 to $1398{ }^{\circ} \mathrm{C}$ (average $1202^{\circ} \mathrm{C}$ ). A pressure of $50 \mathrm{kbar}$ was assumed for the above thermometers. The average mineral inclusion temperatures are within error that obtained from FTIR analysis of $1220^{\circ} \mathrm{C}$. This is likely due to the mineral inclusions recording the temperature of formation and the FTIR temperature recording an average for mantle residence. These diamonds are $40-170{ }^{\circ} \mathrm{C}$ hotter than the average for peridotitic inclusions of $1050{ }^{\circ} \mathrm{C}$ (Harris, 1992). The $\mathrm{Ca}$ in pyroxene barometer of Köhler \& Brey (1990) and the barometer of Nimis \& Taylor (2000) yield average pressures, for an assumed temperature of $1200^{\circ} \mathrm{C}$, of 48 and $50 \mathrm{kbar}$, respectively.

\section{CONCLUSIONS}

The majority of the diamond suite has undergone plastic deformation, evident from the brown colour of the stones (Harris, 1992). The range of carbon isotopes is narrow, suggesting isotopic fractionation from a homogeneous carbon source during the growth of the diamonds. The range for nitrogen isotopes is unusually large and these values cannot solely be explained by isotopic fractionation. The low nitrogen isotope values obtained may be representative of a source containing primitive nitrogen. FTIR analysis of the diamonds shows them to be mostly Type II. Those that contain nitrogen give the same range of temperatures for both the harzburgitic and lherzolitic parageneses, which suggests that the harzburgitic diamonds have recrystallized at $1.93 \mathrm{Ga}$, during the formation of the lherzolitic paragenesis. Cathodoluminesence images 
coupled with FTIR analysis show that the majority of the diamonds analysed exhibit cyclic, octahedral growth. This cycle generally consists of Type I growth followed by some resorption and then limited Type II growth. This cycle indicates the variable nature of nitrogen and carbon in the source medium. The mineral inclusions are compositionally similar to the worldwide ranges for garnet, orthopyroxene, olivine and clinopyroxene. Further investigation into the mineral chemistry and geothermobarometry will help to draw conclusions about trends between the lherzolite and harzburgite parageneses. It is possible that the lherzolitic inclusions originated at a deeper level in the mantle and formed from the re-enrichment of a previously depleted harzburgitic source.

\section{REFERENCES}

Allsopp, H.L. \& Kramers, J.D., 1977. Rb-Sr and U-Pb age determinations on southern African kimberlite pipes. $2^{\text {nd }}$ Int. Kimberlite Conf., Sante Fe, New Mexico, (extended abstracts).

Boyd, S.R. \& Pillinger, C.T., 1994. A preliminary study of ${ }^{15} \mathrm{~N} /{ }^{14} \mathrm{~N}$ in octahedral growth form diamonds. Chem. Geol. 116, 43-59.

Cartigny, P., Boyd, S.R., Harris, J.W. \& Javoy, M., 1997. Nitrogen isotopes in peridotitic diamonds from Fuxian, China: the mantle signature. Terra Nova. 9: 4, 175-179.

Deines, P., Gurney, J.J., Harris, J.W., 1984. Associated chemical and carbon isotopic composition variations in diamonds from Finsch and Premier kimberlite, South Africa. Geochim Cosmochim Acta. 48, 325-342.

Harris, J.W., 1992. Diamond geology. In: J.E. Field (Ed), The properties of diamond, Academic Press, London, pp. 345393.

Harris, J.W. \& Gurney, J.J., 1979. Inclusions in diamond. In: J.E. Field (Ed.), The properties of diamond. Academic Press, London, pp. 555-591.

Köhler, T.P. \& Brey, G.P., 1990. Calcium exchange between olivine and clinopyroxene calibrated as a geothermobarometer for natural peridotites from 2 to $60 \mathrm{~kb}$ with applications. Geochim Cosmochim Acta. 54, 2375-2388.
Krogh, E.J., 1988. The garnet-clinopyroxene Fe-Mg geothermometer - a reinterpretation of existing experimental data. Contrib. Mineral. Petrol. 99, 44-48.

Nimis, P., Taylor, W.R., 2000. Single clinopyroxene thermombarometry for garnet peridotites. Part I. Calibration and testing of a Cr-in-Cpx barometer and an enstatite-in-Cpx thermometer. Contrib. Mineral. Petrol. 139, 541-554.

Richardson, S.H., Harris, J.W. \& Gurney, J.J., 1993. Three generations of diamond from old continental mante. Letters to nature. $366: 18,256-258$.

Stachel, T. \& Harris, J.W., 1997.Diamond precipitation and mantle metasomatism-evidence from the trace element chemistry of silicate inclusions in diamonds from Akwatia, Ghana. Contrib. Mineral. Petrol. 129, 143-154.

Walraven, P., Retief, E.A., Burger, A.J. \& Swanepoel, D.J., 1987. Implications of new U-Pb zircon age dating on the Nebo Granite of the Bushveld Complex. South African Journal of Geology. 90, 344-351. 